\title{
Implicit Theories of Directors in the Exercise of Pedagogical Leadership
}

\author{
Gabriel Vela Quico, Klinge Villalba-Condori
}

\begin{abstract}
This research article seeks to answer two questions: "What are the main Implicit Theories that can be inferred from principals about Pedagogical Leadership in some Alternative Basic Education Centers (CEBA) in Arequipa in a context of educational and teaching reforms?" and "What level of affinity do the Implicit Theories of CEBA principals have with that of their teachers about Pedagogical Leadership? The research was of a descriptive level, with a qualitative approach, and case studies were chosen as the main method. We worked with 10 directors to whom an in-depth interview was applied, which was transcribed and the corresponding analyses were made from this compilation. In addition, a Perceptions Scale was used on the pedagogical management of principals and teachers of CEBA itself. In a complementary manner, the field notebook was applied as a review of documents and tools for the analysis of discourse. The general results reveal that in the provisional categories such as shared vision, teacher training, conditions and results, institutional climate, student protagonism, curricular pertinence, reflection on pedagogical practice and pedagogical accompaniment, and the emerging categories such as access to leadership, role focus, key concept, central purpose, contextual problems, role of principals and specialists, and aspects of $A B E$ normativity, principals have an Administrative-Centered Theory, more Conservative than Renewal Type. The few managers with a Pedagogical Centered Theory are more affiliative than transformative. Likewise, it was found that in general teachers have perceptions that are not aligned with those of their CEBA directors, which makes Pedagogical Leadership complex, making it necessary to build a distributed Pedagogical Leadership in a broad sense, rather than reducing it to the learning processes in the classroom, a fact that should contemplate the trainings promoted by the Ministry of Education.
\end{abstract}

Keywords--- Implicit Theories, Pedagogical Leadership, CEBA.

\section{INTRODUCTION}

Alternative Basic Education in Peru is aimed at students who for some reason could not study in Regular Basic Education, either because they dropped out of school, are older, or because they had to reconcile study and work (General Education Law No. 28044).

In this modality, children, adolescents, young people and adults who generally come from migrant families in the southern sierra and who are underemployed or unemployed, wish to complete their basic education in spite of the limitations and deficiencies (Rivero, 2008).

Implicit Theories are part of the paradigm known as 'Teacher Thought' (Clark and Peterson, 1990), since from this approach not only the actions of the teachers or principal teachers are analyzed, but mainly the thought processes that provoke them.

\footnotetext{
Manuscript received September 16, 2019.

Gabriel Vela Quico, Universidad Nacional de San Agustín De Arequipa, Perú. (e-mail: vela@unsa.edu.pe)

Klinge Villalba-Condori, Universidad Nacional de San Agustín De Arequipa, Perú. (e-mail: kvillalbac@unsa.edu.pe)
}

Here the assumption is that thoughts, beliefs, plans and perceptions influence and determine their behavior. In the case of teachers who occupy managerial functions, management behaviour is, to a large extent, the result both of thought or knowledge and of their strategies for processing information and using it to solve problems in school management.

In other words, Implicit Theories are the logics with which teachers or principals understand the events they perceive in school and guide the actions of their own behaviour in that world.

This knowledge relevant to action is usually tacit (Villalba-Condori, García-Peñalvo, Lavonen, \& Zapata-Ros, 2018).

Pedagogical Leadership, on the other hand, is a work of mobilizing and influencing others to articulate and achieve the school's shared intentions and goals (Leithwood, 2009).

Leadership is a quality of the person or persons who exercise it and can also become a characteristic of CEBA management as an institution, in which people with leadership - formal or informal - participate in a process led by the principal, who coordinates and contributes to the success of the results and goals focused on learning and development.

Pedagogical Leadership in the current Peruvian educational context is endorsed in the Management Good Performance Framework (MBDDir), which was approved with RSG No. 304-2014-MINEDU that points out certain ways to concretize leadership centered on learning (Ministry of Education, 2014).

The model for research has been constructed from an understanding of the cases, varied and nutritious in information, which have served as the basis for the present work. The models are shown below:

\section{Conceptual References}

\section{$A B E$ in the Education System}

Alternative Basic Education is aimed at serving those who did not join the Regular Basic Education or who left the Educational System and whose age prevents them from continuing their regular studies, and also serves those who need to reconcile study and work. That is to say, they work with children, adolescents, young people and adults who come from poor families and are frequently exposed to precarious conditions that threaten their mental and physical health, they work as domestic workers, employees in small businesses, artisans, bricklayers, and an endless number of occasional jobs, they live in places of high population density, exposed to low salaries, sexual harassment by their employers and above all to physical and psychological mistreatment 
Tabla 1: Models of Managerial Leadership in CEBA

\begin{tabular}{|c|c|c|c|c|}
\hline \multirow{3}{*}{ CATEGORIES } & \multicolumn{2}{|c|}{ Administrative Centered Theory TCA } & \multicolumn{2}{|c|}{ Theory Focused on Pedagogical TCP } \\
\hline & Tipo A Conservative & $\begin{array}{l}\text { Tipo B } \\
\text { Renovator }\end{array}$ & Tipo A Affiliation & Tipo B Transformer \\
\hline & (TC) & (TR) & (TA) & (TT) \\
\hline $\begin{array}{l}\text { Access to } \\
\text { Address (1) }\end{array}$ & $\begin{array}{l}\text { (TC1) Power } \\
\text { cravings. }\end{array}$ & $\begin{array}{l}\text { (TR1) Desire to } \\
\text { direct. }\end{array}$ & $\begin{array}{l}\text { (TA1) Hope to } \\
\text { improve } \\
\text { professionally and to } \\
\text { EI. }\end{array}$ & $\begin{array}{l}\text { (TT1) Opportunity to } \\
\text { improve the quality of } \\
\text { education. }\end{array}$ \\
\hline $\begin{array}{l}\text { Pedagogical } \\
\text { Leadership Role } \\
\text { Approach (2) }\end{array}$ & $\begin{array}{l}\text { (TC2) Focused on } \\
\text { the administrative. }\end{array}$ & $\begin{array}{l}\text { (TR2) Focused on the } \\
\text { administrative and } \\
\text { then the pedagogical. }\end{array}$ & $\begin{array}{l}\text { (TA2) Focused on } \\
\text { the formal aspects of } \\
\text { pedagogy. }\end{array}$ & $\begin{array}{l}\text { (TT2) Focused on the } \\
\text { basic aspects of } \\
\text { pedagogy. }\end{array}$ \\
\hline Shared Vision (3) & $\begin{array}{l}\text { (TC3) Simple } \\
\text { conception of vision } \\
\text { or given by the } \\
\text { Ministry of } \\
\text { Education. }\end{array}$ & $\begin{array}{l}\text { (TR3) Vision built by } \\
\text { the director in his } \\
\text { management. }\end{array}$ & $\begin{array}{l}\text { (TA3) Common } \\
\text { vision elaborated } \\
\text { essentially with } \\
\text { teachers. }\end{array}$ & $\begin{array}{l}\text { (TT3) A vision } \\
\text { elaborated, shared, and } \\
\text { led by the principal, } \\
\text { teachers, and students. }\end{array}$ \\
\hline $\begin{array}{l}\text { Teacher Capacity } \\
\text { Building (4) }\end{array}$ & $\begin{array}{l}\text { (TC4) Train their } \\
\text { teachers to comply } \\
\text { with the Ministry's } \\
\text { requirements. To } \\
\text { press. }\end{array}$ & $\begin{array}{l}\text { (TR4) Train their } \\
\text { teachers on the basis of } \\
\text { Ministry regulations. } \\
\text { Improve. }\end{array}$ & $\begin{array}{l}\text { (TA4) Teacher } \\
\text { training for their } \\
\text { students to pass. } \\
\text { Facilitate. }\end{array}$ & $\begin{array}{l}\text { (TT4) Comprehensive } \\
\text { training with a focus on } \\
\text { "multi-purpose teachers" } \\
\text { in ABE. Liberate. }\end{array}$ \\
\hline $\begin{array}{l}\text { Commitments to } \\
\text { Learning } \\
\text { Conditions and } \\
\text { Outcomes (5) } \\
\end{array}$ & $\begin{array}{l}\text { (TC5) Provider of } \\
\text { teaching resources. }\end{array}$ & $\begin{array}{l}\text { (TR5) Provider of } \\
\text { resources to improve } \\
\text { the effectiveness of } \\
\text { CEBA. }\end{array}$ & $\begin{array}{l}\text { (TA5) Search for } \\
\text { learning from the } \\
\text { conditions of } \\
\text { teaching comfort. }\end{array}$ & $\begin{array}{l}\text { (TT5) Ensure all } \\
\text { conditions of educability } \\
\text { of the student. }\end{array}$ \\
\hline $\begin{array}{l}\text { Institutional } \\
\text { Climate (6) }\end{array}$ & $\begin{array}{l}\text { (TC6) Avoid } \\
\text { conflict. }\end{array}$ & $\begin{array}{l}\text { (TR6) Accept the } \\
\text { conflict. }\end{array}$ & $\begin{array}{l}\text { (TA6) Resolve } \\
\text { conflicts. }\end{array}$ & $\begin{array}{l}\text { (TT6) Manages } \\
\text { conflicts. }\end{array}$ \\
\hline $\begin{array}{l}\text { Student } \\
\text { Protagonism (7) }\end{array}$ & $\begin{array}{l}\text { (TC7) Formal, } \\
\text { decorative and } \\
\text { instrumental. }\end{array}$ & $\begin{array}{l}\text { (TR7) Formal, } \\
\text { important and } \\
\text { autonomous. }\end{array}$ & $\begin{array}{l}\text { (TA7) Promotes, } \\
\text { necessary for } \\
\text { coexistence. }\end{array}$ & $\begin{array}{l}\text { (TT7) Protagonism, an } \\
\text { essential actor in } \\
\text { management. }\end{array}$ \\
\hline $\begin{array}{l}\text { Curricular } \\
\text { Relevance }(8)\end{array}$ & $\begin{array}{l}\text { (TC8) Curriculum as } \\
\text { required by the } \\
\text { Ministry. }\end{array}$ & $\begin{array}{l}\text { (TR8) Enriched } \\
\text { curriculum in each } \\
\text { CEBA. }\end{array}$ & $\begin{array}{l}\text { (TA8) Build } \\
\text { curriculum } \\
\text { according to } \\
\text { students. }\end{array}$ & $\begin{array}{l}\text { (TT8) Builds curriculum } \\
\text { according to life } \\
\text { situations and local and } \\
\text { global context. }\end{array}$ \\
\hline $\begin{array}{l}\text { Teacher } \\
\text { Accompaniment } \\
(9)\end{array}$ & $\begin{array}{l}\text { (TC9) Type of } \\
\text { control or } \\
\text { permissiveness. }\end{array}$ & $\begin{array}{l}\text { (TR9) Control with } \\
\text { teacher support. }\end{array}$ & $\begin{array}{l}\text { (TA9) It } \\
\text { accompanies but } \\
\text { avoids conflicts with } \\
\text { teachers. }\end{array}$ & $\begin{array}{l}\text { (TT9) Accompanies to } \\
\text { ensure learning } \\
\text { achievement. }\end{array}$ \\
\hline $\begin{array}{l}\text { Verification of } \\
\text { Learning } \\
\text { Achievements } \\
\text { (10) }\end{array}$ & $\begin{array}{l}\text { (TC10) There's no } \\
\text { information. }\end{array}$ & $\begin{array}{l}\text { (TR10) You have } \\
\text { minimal information. }\end{array}$ & $\begin{array}{l}\text { (TA10) You value } \\
\text { its importance, you } \\
\text { have basic } \\
\text { information. }\end{array}$ & $\begin{array}{l}\text { (TT10) It is } \\
\text { institutionally valued, } \\
\text { registered and monitored. }\end{array}$ \\
\hline Key Concept (11) & $\begin{array}{l}\text { (TC11) Education is } \\
\text { a service and learning } \\
\text { is a behaviour } \\
\text { change. }\end{array}$ & $\begin{array}{l}\text { (TR11) Education is a } \\
\text { service and learning is } \\
\text { a change of behaviour } \\
\text { and construction. }\end{array}$ & $\begin{array}{l}\text { (TA11) Education } \\
\text { is a right and } \\
\text { learning is a process } \\
\text { of individual } \\
\text { construction. }\end{array}$ & $\begin{array}{l}\text { (TT11) Education is a } \\
\text { right and learning is a } \\
\text { process of individual and } \\
\text { social construction. }\end{array}$ \\
\hline $\begin{array}{l}\text { Central Purpose } \\
(12)\end{array}$ & (TC12) Teach. & $\begin{array}{l}\text { (TR12) Teach, } \\
\text { educate. }\end{array}$ & $\begin{array}{l}\text { (TA12) Train } \\
\text { people. }\end{array}$ & $\begin{array}{l}\text { (TT12) Forming } \\
\text { citizens. }\end{array}$ \\
\hline $\begin{array}{l}\text { Contextual } \\
\text { Problems (13) }\end{array}$ & $\begin{array}{l}\text { (TC13) They } \\
\text { determine the reality } \\
\text { of CEBA. }\end{array}$ & $\begin{array}{l}\text { (TR13) They } \\
\text { influence the internal } \\
\text { reality of CEBA. }\end{array}$ & $\begin{array}{l}\text { (TA13) They } \\
\text { condition the } \\
\text { practice of CEBA. }\end{array}$ & $\begin{array}{l}\text { (TT13) They challenge } \\
\text { or challenge the work in } \\
\text { CEBA. }\end{array}$ \\
\hline $\begin{array}{l}\text { Role of Directors } \\
\text { and Specialists } \\
\text { (14) }\end{array}$ & (TC14) They control. & $\begin{array}{l}\text { (TR14) They control, } \\
\text { they supervise. }\end{array}$ & $\begin{array}{l}\text { (TA14) They } \\
\text { control and } \\
\text { accompany. }\end{array}$ & (TT14) Lead. \\
\hline Regulations (15) & (TC15) Abide. & $\begin{array}{l}\text { (TR15) Abide by what } \\
\text { you can. }\end{array}$ & $\begin{array}{l}\text { (TA15) Protect } \\
\text { from threats. }\end{array}$ & $\begin{array}{l}\text { (TT15) Take advantage } \\
\text { of opportunities. }\end{array}$ \\
\hline
\end{tabular}

Source: Adapted from Leithwood's own Effective Leadership (2009); and Bolívar's Leadership for Learning (2010).

This modality seeks to provide a range of services Program for Youth and Adults (PEBAJA) and Literacy adapted to demand and not to supply, through various forms of care: face-to-face, blended and distance. Its institutionalized form are the Alternative Basic Education Centers (CEBA), which can offer students one or two programs of the modality: Alternative Basic Education 
Jóvenes y Adultos). In all cases, there are possibilities not only for those who aspire to continue their higher education, but also for those who seek useful learning for family, civic and productive life, and need to have the tools to continue educating themselves through self-learning processes, as projected by the 2005-2010 Plan for the Conversion of Basic Alternative Education, promoted by the Ministry of Education.

\section{The Framework for the Construction of Alternative Basic Education}

De Martínez and Cárdenas (2014) have an important reflection: they point out that, at the initiative of the Ministry of Education, a multipurpose team of specialists with experience in the education of children and adolescents and young people and adults was formed, which was in charge of elaborating the framework for the construction of $\mathrm{ABE}$, which this team rightly called The Other Education. The explicit purpose of the proposal was to overcome the limitations of the traditional night school for youth and adults. Consequently, it proposed a greater dimension of the meaning of education, beyond the enunciative discourse on the human person as the 'center' of educational activity. It considered the person as the raison d'être of an education towards development, starting from recognizing the processes of life as processes of knowledge in which people know themselves as subjects of their own personal and collective life.

Nevertheless, they clarify, in front of the anthropocentric vision of emphasizing individuality, this vision can be enriched with other worldviews, such as those of our original populations, if it is considered that "the notion of rune does not define an indivisible and self-contained unity involves the human, but of which the non-human, nature or the Andean deities or wacas also participate" (Degregori et al., 2001).

\section{Implicit Theories in the Directive Exercise of a CEBA}

For Pozo, Scheuer, Mateos and Pérez (2006), spontaneous theories (Implicit Theories) are basically three: direct theory, interpretive theory and constructive theory. Direct theory, with the epistemological assumption that knowledge is a faithful copy of reality, reduces learning to the reproduction of stimuli or behaviors without the mediation of higher psychological processes. It assumes a dualistic conception of knowledge, conceiving the subject and the object as separate entities, an object that exists independently of the subject and that can be studied objectively (without bias) by a subject external to it. According to Pozo and others (2006), it is related to a behavioral vision of learning.

Interpretive theory preserves the epistemological assumption of the previous approach, but learning is the result of the personal activity of the subject, who operates with a series of mediating psychological processes. This theory is close to the models of information processing which, although it represents active learning, is equally reproductive. Constructivist theory admits the existence of multiple knowledges, perspectivism and relativism. All knowledge is a contextualized construction and, therefore, relative and with different degrees of certainty. Learning of body and mind but a network, a tissue of bodies that

involves reconstructive mental processes of one's own previous representations in dialogue with the new content. The learner is aware of the conditions in which learning occurs, which implies self-regulation of one's own activity and an adjustment of the metacognitive processes that regulate one's learning.

\section{Pedagogical Leadership Practices in ABE}

In a historical review of the different proposals for leadership models, we have several (strategic, sustainable, servant, emotional, ethical, transactional, etc.), of which the two most powerful have been pedagogical leadership, coming from the "effective schools" movement, and "transformative" leadership, linked to the school restructuring movement. In principle it is obvious that a CEBA, like any EI, is for students to learn and develop in a more pertinent sense, so a leadership should focus its attention and be measured by its contribution to the achievement of learning. It is possible to discuss what is meant by "learning" and what is included within this expression, but it is a realistic approach to turn EI around in what students actually achieve in their formative process (Bolívar, 2010).

In some European countries it has been concluded that the ability of a school to improve depends, in a significant way, on leaders who actively contribute to dynamise, support and encourage their school to learn to develop, doing things progressively better. However, by leadership we mean the ability, not based on formal power or authority, to exert influence on other people. When this influence is aimed at improving learning, we speak of Pedagogical Leadership.

The change of the directive function in the 21 st century is to create schools that assure, to all the students and in all the places, a good education. The main agenda in the exercise of management of educational institutions is leadership for learning that is, linking leadership with student learning. EI must ensure that all students have basic skills. Therefore, a leadership for learning takes as the core of its action the quality of the teaching offered and the learning outcomes achieved by the students. The priority issue is which management practices create a context for a better work of teachers -and, jointly, of the whole CEBA-, shared by other members of the teaching team, as a quality of the organization.

\section{METHOD}

The research was approached as a qualitative study, as the case study was used. It was determined 10 CEBA from characteristics that provide the Advanced Cycle, are of the same UGEL and combine directors ratified in the position as new directors. The following instruments were applied: Indepth Interview and Scale of Perceptions.

As the interview data was organized, they were reviewed to make sure that the information was sufficient to undertake the analysis and if it was adequately established in each category. Subsequently, it was necessary to identify to which type of Implicit Theory (Administrative Centered

Published By:
\& Sciences Publication 
Theory, be it type A "conservative" or type B "renovator" or Pedagogical Centered Theory, type A "affiliative" or type B "transformer") each of the statements obtained corresponded. To facilitate typing, it was coded on the basis of descriptors corresponding to the research categories.

From the great diversity of qualitative research analysis techniques, direct interpretation and categorical sum were chosen because, in Stake's words, "the case study is based on both methods" (1999, p. 69). These two techniques are oriented to the search of correspondence between the aspects defined on Pedagogical Leadership, both in the manifestations of the directors in the interview and in the scale of perception applied to teachers and directors; for it, the Implicit Theories of the directors on Pedagogical Leadership in the CEBA were related. Through direct interpretation and based on the aspects of Pedagogical Leadership in the CEBA, it was defined in which of the Implicit Theories the directors under study are located. Finally, a categorical sum was made in order to approximate the theories that emerge from the data collected. According to Strauss and Corbin (2002), this occurs from the fact that significant representations are constituted to conform a greater scheme; in this way the discoveries of the study reach the form of theory.

Eight categories were proposed: shared vision, teacher capacity building, commitments to learning conditions and outcomes, institutional climate, student protagonism, curriculum development, teacher accompaniment, and verification of learning achievement. Likewise, emerging categories were incorporated into the research, such as access to management, management role approach, key concepts such as education and learning, among others.

\section{RESULTS}

As for the Implicit Theories of the category motivations for access to the management of a CEBA, the motivations for occupying the position and the sense of belonging and perseverance in it were investigated. In this category, it can be seen that 6 out of 10 directors are located within the Administrative Focused Theory, 3 in the Conservative Type A and 3 in the Renewable Type B; while 4 correspond to the Pedagogical Focused Theory, 2 in the Affiliative Type A and 2 in the Transformer Type B.

In this category, 6 out of 10 directors are located within the Administrative Focused Theory, 3 in the Conservative Type A and 3 in the Renewable Type B; while 4 correspond to the Pedagogical Focused Theory, 2 in the Affiliative Type A and 2 in the Transformer Type B. The Conservative Type (TC) existence is expressed in that such directors have the desire to occupy the position basically by showing power, as a personal conquest. For example:-

"...it was a challenge to occupy a position as a manager because I had many projects in mind to put into practice,... I also like the administrative work ..." (ED6.P1)

They also explored their beliefs about staying in the same CEBA or moving to another, and the probable conditions or expectations expressed by the subject. We have found 6 directors with TCA and 4 with TCP. Only one director has an Implicit Theory of a conservative type and another of a transforming type.

The existence of TCA is expressed in the tendency to remain in office for reasons of personal comfort or convenience; they do not manifest greater desires for changes or routes to follow in a process of occupying the directorship for three years, nor do they evidence plans or ideals. For example:

- "Well, I think that a director should be able to work in any CEBA, right? The important thing is to assume the challenges and know how to respond at that moment." (ED3.P25)

As for the Implicit Theories of the category approach to the role of Pedagogical Leadership, it was investigated whether the principal involves the teaching staff in the key aspirations of CEBA, which leads to the identification of legal frameworks as visions of what is expected to be achieved. It was found that 6 out of 10 principals have an ATT, that is, in their representations of the new managerial role, they tend to ultimately retain the old school structure. There is even a predominance of being conservative that is, focusing on the use of power. The key words that express equivalence with leadership were "to be an example", "to go to the vanguard", "to direct", "quality", "is the head", all of them under the classic perspective of the exercise of the position of director. In general, the typical role assumed is that of "pastor". For example:

- "It's a way of having other teachers follow a person in order to be able to improve". (ED4.TP2)

It can also be seen that there is a tendency to be affiliative, which implies avoiding problems in the position, essentially with teachers; this comes from perceiving institutional management in a way that focuses on "avoiding conflict", "harmonizing", "taking care of peace at work" or even "knowing how to carry the party in peace". There are therefore some directors who are docile or fearful of change, who think more of teachers than of students, for example:

- "It is to motivate, to contribute to the development of CEBA, starting from the teachers and benefiting the students.". (ED9.TP2)

As for the Implicit Theories of the shared vision category, CEBA understood the institutional vision as a photograph of the future, capable of mobilizing people and resources to achieve a possible dream. Without vision, a CEBA gropes because it does not know what it wants to achieve in the future. Seven out of 10 directors were found to be within the Administrative Centered Theory; six in Type A Conservative and one in Type B Renewable. On the other hand, 3 follow the Theory Focused on the Pedagogical; and all are of Type A Affiliative. The predominance of the Conservative Type (TC) is expressed in that these directors have a superficial understanding of the shared vision without making reference to the fact that it is the articulating element of the Institutional Educational Project (PEI) and that it is concretized in the execution of the Annual Work Plan. We register, for example, this declaration:

- "...the participation that the entire educational community has to have with respect to the pedagogical aspect". (ED1.P3) 
- It is a process that will allow the development, both... the institutional development, of both teachers and students, in our educational centers, and this is going to lead to better learning achievements... something that the education offered in CEBA is going to be, this is going to be, an education that achieves significant learning.". (ED5.P3)

As for the Implicit Theories on teacher capacity building, both the teacher training perspective and the stimulus policy were investigated. It was found that 7 out of 10 CEBA principals have an ACT, of which 5 are of a renovating type and 2 of a conservative type. Thus, beyond the efforts they might make to evidence a new discourse, principals continue to be trapped in placing emphasis on the hierarchical, of "applying" what has been decreed by the Ministry of Education. For example:

- "I think that's important because it allows us to have a better overview so that everyone from the classrooms begins to implement all that kind of knowledge that works.". (ED4.P5).

Additionally, it is common to criticize the impossibility of carrying out training actions due to external factors, which is why strategies are used that are not very effective or that do not guarantee greater teacher learning. For example:

- “...I have always been a participant and I have communicated to my teachers that the most important thing is self-education, self-training, self-actualization. Unfortunately, the Ministry of Education does not allocate the necessary resources for ABE to carry out, for example, face-to-face training cycles...." (ED10.P5)

Regarding stimuli, it was found that 5 managers have an ATT and 5 have a TCP. Ratified executives tend to be affiliated. The majority of principals consider giving recognitions so that their teachers are motivated to work or feel more committed to work at CEBA. The affiliative character of the stimuli is centered on the improvement of the teacher (up the teacher scale) and not necessarily on the learning of the students or on raising the professionalism of corresponds to being functional to the provisions of the Ministry of Education:

- "...Just as the resolutions of the UGEL must have transcendence, MINEDU itself, of value. So that they too, on the basis of healthy competition, also begin to improve their participation, their educational level". (ED1.P8)

As for Implicit Theories, their organization is redefined in an institutional climate. Three subcategories were investigated that together allow us to identify what theory the director of CEBA evidences in terms of what they think and also what they use about the type of school management: whether the management is open or collaborative, whether it is an informed management and whether it is a democratic management. In addition, it was of a conservative type, which perceives the institutional climate as a resource to avoid conflict, since a ABSC with a good climate would be one that does not have conflicts or that accepts them as something negative that harms management. None of them expressed their appreciation of the importance of resolving conflicts or, better, managing the teacher. From a conservative theory, this responds and found that 9 out of 10 directors have an ATT, predominantly

conflicts. It is one thing to accept the conflict; another to celebrate it. For example:

- "...just as they are already knowing that they are going to be evaluated, they are going to be monitored with respect to it, so that is also a way for them to do things well as well.". (ED1.P11)

As for the results of the Scale of Perception on Pedagogical Leadership of the director and teachers of CEBA, Implicit Theories expressed in the basic concepts of education and learning by the directors of CEBA were investigated. From the analysis of all the answers of the directors we have: 3 directors are "Completely in agreement" and 7 directors are "In agreement". In this sense, we can infer that the directors of CEBA put into practice an Implicit Behavioral Theory of Learning, which marks a still weak approach to accompany and lead the pedagogical work in their respective CEBA. On the central purpose, it was found that 3 directors are "Completely in agreement", 3 directors are "In agreement", 3 in "Disagreement" and 1 director is "Indecisive". It can be inferred that they handle very dissimilar Implicit Theories. There is no trend or consensus.

As for the results of the Director's Perceptions Scale and the alignment with CEBA's teachers on Pedagogical Leadership, it was found that the investigated principals, in general, have very little affinity with the conceptions and beliefs held by the teachers, which would make it difficult to fully exercise Pedagogical Leadership both in the ratified principals and in those who recently acceded to the position, being very important in a context of educational reforms that Peruvian education is experiencing, expressed both in norms (MBDDir and others) and in school work strategies. For example, in the case of CEBA 7, located in the lower part of a district whose area of influence is quite large but whose enrolment situation is not massive. Four teachers were investigated, of whom two are men and two are women; the average time of service is 20 years; it was found that out of 12 items only in 3 of the affirmations there is consensus among them and only 1 has affinity with the perceptions of the principal (learning concept); therefore, it can be inferred that in the case of this principal, her perceptions practically do not coincide at all with those of her teachers in the different criteria on pedagogical management.

\section{DISCUSSION}

Modern societies tend towards the development of education as a means of integrating people with their needs and the requirements of the State, as well as facing the demands of the knowledge-based and globalized society (Rodríguez-Molina, 2011). In this sense, education allows the transformation of human capital (Mogollón, 2006) in order to increase productivity, knowledge management and science, in function of the development of the intellectual capital of the countries and the formation of citizens for an active participation within the political-social context. This development leads to the formation of citizens committed to 
their institutions, making them participate fully in democratic and economic activities that lead to change the country (Carnoy, 2008).

Change does not only involve assuming the commitment to enforce the norms, but also taking on challenges from the first link in the education system: schools have the mission not only to spread knowledge but also values and ideas that allow them to shape society. There are many factors that help schools fulfill their function. These include pedagogical leadership, which combines teaching and management (Carriego, 2006). Pedagogical leadership is oriented towards the organization of good pedagogical practices and the increase of learning outcomes (Bolívar, 2010). For Freire and Miranda (2014), principals who adopt this style of leadership become more involved in the development of the school curriculum. They also help to harmonize instruction with educational objectives, without setting individualistic or conservative tendencies. Adequate pedagogical leadership will allow teachers to develop professionally, since, rather than ordering or sanctioning, what it promotes is to have an impact on improving pedagogical practice through the evaluation of student learning based on the results achieved (Murillo 2007; Organization for Economic Cooperation and Development 2010).

The management and institutional planning practices of school principals and teachers are conditioned by their understanding of these processes. Personal and professional histories as well as diverse social and cultural changes construct a way of representing the tasks of managing and planning an institution in a particular way (Macchiarola and Martín, 2007). These representations are called implicit theories. These theories are the product "of the construction of the world through the body, personal experience and implicit learning" (Macchiarola and Martín, 2007, p. 355). Although these constructions have a direct impact on teaching, their nature is internal, structured and systematized; hence their implicit and theoretical character.

Optimal leadership should focus on its contribution to improving learning. However, there is a tendency to focus efforts on improving purely organizational and dimensional aspects such as the execution of tasks and functions, satisfaction and problems, among others (Bolívar, 2010).

Thus, the incidence of good leadership in improving student learning is neglected, since good management influences the improvement of the ways in which teachers organize and carry out teaching and the way students learn. In recent years, several studies have focused on the importance of pedagogical leadership (Marzano, Waters and McNulty, 2005), demonstrating how important its impact is on students' learning levels, especially in those situations where disadvantaged situations prevail.The results obtained in the present study show a greater presence of theory centered on the administrative rather than the pedagogical. Thus, 6 of the 10 directors interviewed are located within the Theory Focused on the Administrative, being the types with the greatest presence the Conservative Type A and the Renewing Type B (3 participants each); while 6 directors of the 10 manifest a TCA and 4 a TCP. Only one director has an Implicit Theory of conservative type and another of transformer type. This predominance evidences that the idea that one seeks to remain in office for reasons of comfort or personal convenience, without manifesting greater desires for changes or routes to follow in a process of occupying the office for three years, nor evidencing plans or ideals.

As for the Implicit Theories of the category approach to the role of Pedagogical Leadership, it was found that 6 of the 10 principals have an ATT, that is, in their representations of the new managerial role they tend to faithfully preserve the old school structure. It can also be seen that there is a tendency to be affiliative, that is, not to have problems in the position, essentially with teachers; this makes them perceive the institutional climate with an attitude of "avoiding conflict", "harmonizing", "taking care of the peace of work" or even "knowing how to carry the party in peace". As for the shared vision of the institution, the interviewees conceive it as a photograph of the future that allows people and resources to be mobilized to achieve a possible dream. Without vision, a CEBA gropes because it does not know what it wants to achieve in the future. It was found that 7 out of 10 directors are located within the Administrative Centered Theory; 6 in Type A Conservative; and 1 in Type B Renewal. On the other hand, 3 correspond to the Theory Centered on the Pedagogical, being all of Type A Affiliative. The predominance of the Conservative Type (TC) is expressed in that these directors have a superficial understanding of the shared vision without making reference to the fact that it is the articulating element of the Institutional Educational Project (PEI) and that it is concretized in the execution of the Annual Work Plan.

Regarding the Results of the Principal's Perceptions Scale and the alignment with the CEBA teachers on Pedagogical Leadership, it was found that the investigated principals have, in general, very little affinity with the conceptions and beliefs of the teachers, which would make it difficult to fully exercise Pedagogical Leadership both in the ratified principals and in those who recently acceded to the position, a very important circumstance in a context of educational reforms.

These results show a lack of application of a shared leadership, that is to say, that the image of leader should not fall solely on one person, the same person who exercises power from his position, but it is desirable that his work be distributed among all members. In this sense, to think that leadership in itself is the solution to problems leads to a distortion of solutions.

\section{REFERENCES}

1. BOLÍVAR, Antonio (2010). "El liderazgo educativo y su papel en la mejora: Una revisión actual de sus posibilidades y limitaciones", Psicoperspectivas, vol. 9, núm. $2, \quad$ pp. $9-33, \quad$ en: https://scielo.conicyt.cl/pdf/psicop/v9n2/art02.pdf

2. CARNOY, Martín (2008). Mejorando la calidad y la equidad de la educación en América Latina, en: http://www.ceppe.cl/recursos/presentaciones.

3. CARRIEGO, Cristina (2006). "Gestionar una escuela comprometida con las demandas de su tiempo", Iberoamericana de Educación, vol. 39, núm. 2, pp. 1-5. 
5. CLARK, M.C. y Peterson P.L. (1990). "Procesos de pensamiento de los docentes", en M.C. Wittrock (coord.) La investigación en la enseñanza, III. Profesores y alumnos. Barcelona, Paidós/MEC.

6. DEGREGORI, Carlos Iván; Javier Ávila y Pablo Sandoval (2001). Enseñanza de Antropología en el Perú, Lima, Consorcio de Investigación Económica y Social; Instituto de Estudios Peruanos.

7. Deori, B. (2015). An analysis of rural poverty alleviation programs and challenge in Assam: a micro level study of margherita block of tinsukia district. International Research Journal of Management, IT and Social Sciences, 2(7), 10-14. Retrieved from https://sloap.org/journals/index.php/irjmis/article/view/3 13

8. FREIRE, Silvana y Alejandra Miranda (2014). El rol del director en la escuela: el liderazgo pedagógico y su incidencia sobre el rendimiento académico, Lima, GRADE.

9. Indriyani, N. P. (2015). Lexical meaning: the beginning. International Research Journal of Management, IT and Social Sciences, 2(7), 20-24. Retrieved from https://sloap.org/journals/index.php/irjmis/article/view/3 15

10. LEITHWOOD, Kenneth (2009). ¿Cómo liderar nuestras escuelas? Aportes desde la investigación, Santiago de Chile, Impreso en Salesianos.

11. MACCHIAROLA, Viviana y Elena Martín (2007). "Teorías implícitas sobre la planificación educativa", Revista de Educación, vol. 343, pp. 353-380, en: http://www.revistaeducacion.mec.es/re343/re343_16.pdf

12. MARTÍNEZ, Manuel y Manuel Cárdenas (2014). Hagamos educación alternativa desde nosotros mismos. Estudio sobre la situación pedagógica y normativa de docentes de Educación Básica en Lima y Ayacucho, Lima, Tarea/ Universidad Antonio Ruiz de Montoya.

13. MARZANO, Robert, Timothy Waters y Bryan McNulty (2005). School leadership that works: From research to results. Alexandria, Association for Supervision and Curriculum Development.

14. MINISTERIO DE EDUCACIÓN (2014). Marco de Buen Desempeño del Directivo, Lima, MINEDU.

15. MINISTERIO DE EDUCACIÓN (2015), Términos de referencia para la implementación de la segunda especialidad con mención en "Gestión Escolar con Liderazgo Pedagógico" del programa nacional de formación y capacitación para directores y subdirectores de instituciones educativas públicas. (Documento de trabajo)

16. Netra, I. M. (2015). Meaning configuration of cultural practices in Bali as a model to strengthen identity of Balinese people. International Research Journal of Management, IT and Social Sciences, 2(7), 25-32. Retrieved from https://sloap.org/journals/index.php/irjmis/article/view/3 16

17. MOGOLLÓN, Amada (2006). "Calidad y enfoques de la supervisión”, Revista Ciencias de la Educación, vol. 1, núm. 23, pp. 29-46.

18. MURILLO, Javier (coord.) (2007). Investigación iberoamericana sobre eficacia escolar, Bogotá, Convenio Andrés Bello.

19. ORGANIZACIÓN PARA LA COOPERACIÓN Y DESARROLLO ECONÓMICOS (2010). TALIS 2008. Technical report, en: https://www.oecd.org/education/school/44978960.pdf

20. POZO, Juan; Nora Scheuer; María del Mar Mateos y María del Puy Pérez (2006). "Las concepciones de los profesores de educación primaria sobre la enseñanza y el aprendizaje", en Juan Pozo, Nora Scheuer, María del Puy Pérez, María del Mar Mateos, Elena Martín y Monserrat de la Cruz (coords.), Nuevas formas de pensar la enseñanza y el aprendizaje, Barcelona, Graó, pp. 171188.

21. RIVERO, José (2008). Situación presente de la educación de personas jóvenes y adultas en Perú, México, CREFAL.

22. RODRÍGUEZ-MOLINA, Guillermo (2011). "Funciones y rasgos del liderazgo pedagógico en los centros de enseñanza”, Educ., vol. 14, núm. 2, pp. 253-267.

23. STAKE, Robert (1999). Investigación con estudio de casos, Madrid, Morata.

24. STRAUSS, Anselm y Juliet Corbin (2002). Bases de la investigación cualitativa. Técnicas y procedimientos para desarrollar la teoría fundamentada, Bogotá, Contus/Facultad de Enfermería-Universidad de Antioquia.

25. Suman Rajest S, Dr. P. Suresh, "An Analysis of Psychological Aspects in Student-Centered Learning Activities and Different Methods" in Journal of International Pharmaceutical Research (JIPR), Volume: 46, Special Issue 01, March 2019, Page No.: 165-172.

26. VILLALBA-CONDORI, K. O., GARCÍA-PEÑALVO, F. J., LAVONEN, J., \& ZAPATA-ROS, M. (2018). What kinds of innovations do we need in education?. In proceedings of The II Congreso Internacional de tendencias en Innovación Educativa (CITIE 2018),Villalba-Condori, K. O., García-Peñalvo, F. J., Lavonen, J., \& Zapata-Ros, M. (Eds.) at the CEUR Workshop 2302, 9-15 from http://ceur-ws.org/Vol2302/paper0.pdf 